профессор, академик НАAН Украины, заведующий кафедрой административного менеджмента и альтернативных источников энергии, Винницкий национальный аграрный университет (21008, г. Винница, ул. Солнечная, 3, e-mail: rector@vsau.org).

ГОНТАРУК Ярослав Викторович - ассистент кафедры аграрного менеджмента, Винницкий национальный аграрный университет (21008, г. Винница, ул. Солнечная, 3, e-mail: e050122015@gmail.com).

ПОНЯТІЙНИЙ АПАРАТ
КАТЕГОРІЇ
СІЛЬСКОГОСПОДАРСЬКІ
ВІДХОДИ, ЇХ
КЛАСИФІКАЦІ ТА
ПЕРСПЕКТИВИ
ПОДАЛЬШОГО
ВИКОРИСТАННЯ ДЛЯ
ВИРОБНИЦТВА
БІОЕНЕРГІЇ

ГОНЧАРУК І.В., кандидат економічних наук, доцент кафедри економіки,

ВОВК В.Ю., аспірантка першого року навчання кафедри економіки Вінницький національний аграрний університет (м. Вінниця)

У статті досліджено трактування поняття «відходи» у європейських та вітчизняних нормативних документах та виявлено відсутність у визначеннях екологічної складової, щзо сьогодні є надзвичайно важливим аспектом здійснення будь-якого виду діяльності. Приділено увагу важливій групі відходів - сільськогосподарським відходам, які одночасно здійснюють найбільш негативний вплив на довкілля і можуть бути використані у якості вторинної сировини для забезпечення діяльності інших галузей. Наведено перелік європейських та вітчизняних нормативно-правових документів, які частково регулюють різні аспекти поводження із сільськогосподарськими відходами та виявлено відсутність як у нормативних документах, так і серед наукових підходів до визначення сутності відходів АПК, у зв'язку із цим представлено авторське розуміння даної категорії відходів. Також здійснено порівняння класифікаиії сільськогосподарських відходів відповідно до Державного класифікатора відходів України ДК 005-96 із класифікацією відповідної групи відходів, наведеної у Європейському каталозі відходів.

Проаналізовано обсяги утворення відходів в Україні за видами економічної діяльності y 2019 рочі. Вивчено структуру викидів АПК України $i$ зазначено, щзо найбільшими забруднювачами навколишнього середовища є відходи твариннищтва (гній тварин та послід птиці), проте сьогодні існують шляхи перетворення таких відходів на біопалива, а саме біогаз. Здійснення процесу переробки відходів тваринництва (гною тварин та посліду птиці, які є побічними продуктами виробництва і які не потрібно вирощувати додатково) на біогаз, 
забезпечить не тільки екологічну складову поводження з відходами - зменшення викидів парникових газів, але і надасть додаткові економічні вигоди.

Даним дослідженням встановлено, щзо переробка відходів тваринництва, з утворенням біогазу, дасть змогу частково розв'язати екологічні проблеми, а також отримати переваги у вигляді децентралізованого виробництва відновлюваної енергії або виробництва палива для формування енергетичної незалежності сільськогосподарської галузі України та держави в цілому.

Ключові слова: енергетична незалежність, агропромисловий комплекс, сільськогосподарські відходи, тваринництво, біопаливо, біогаз, екологічна безпека.

Табл.: 2. Рис.: 2. Літ.: 25.

\title{
CONCEPTUAL APPARATUS OF THE CATEGORY OF AGRICULTURAL WASTE, THEIR CLASSIFICATION AND PROSPECTS OF FURTHER USE FOR BIOENERGY PRODUCTION
}

\author{
HONCHARUK Inna, \\ PhD in Economics, \\ Associate Professor, Department of Economics,
} graduate student of the first year of study Department of Economics Vinnytsia National Agrarian University (Vinnytsia)

The article examines the interpretation of the concept of «waste» in European and domestic regulatory documents and reveals the absence of an environmental component in the definitions, which today is an extremely important aspect of any kind of activity. Attention is paid to an important group of waste - agricultural waste, which simultaneously have the most negative impact on the environment and can be used as a secondary raw material to support the activities of other industries. Attention is paid to an important group of waste - agricultural waste, which simultaneously have the most negative impact on the environment and can be used as a secondary raw material to support the activities of other industries. A list of European and domestic regulatory documents that partially regulate various aspects of agricultural waste management is provided, and the lack of both in regulatory documents and among scientific approaches to determining the essence of agricultural waste is provided, in this regard, the author's understanding is presented of this category of waste. Also, a comparison was made between the classification of agricultural waste in accordance with the State Waste Classifier of Ukraine DK 005-96 with the classification of the corresponding waste group given in the European Waste Catalog.

Analyzed the volumes of waste generation in Ukraine by type of economic activity in 2019. The structure of emissions from the agro-industrial complex of Ukraine has been studied and it is indicated that the largest environmental pollutants are animal waste (animal manure and bird droppings), but today there are ways of converting such waste into biofuels, namely biogas. The implementation of the process of processing animal waste (animal manure and bird droppings, which are by-products of production and which do not need to be grown additionally) into biogas, will provide not only the environmental component of waste management - reducing greenhouse gas 
emissions, but also provide additional economic benefits.

This study found that the processing of animal waste, with the formation of biogas, will partially solve environmental problems, as well as gain advantages in the form of decentralized production of renewable energy or fuel production for the formation of energy independence of the agricultural sector of Ukraine and the state as a whole.

Key words: energy independence, agro-industrial complex, agricultural waste, animal husbandry, biofuel, biogas, environmental safety.

Tabl.: 2. Fig.: 2. Lit.: 25.

\title{
ПОНЯТЕЙНЫЙ АППАРАТ КАТЕГОРИИ СЕЛЬСКОХОЗЯЙСТВЕННЫХ ОТХОДОВ, ИХ КЛАССИФИКАЦИЯ И ПЕРСПЕКТИВЫ ДАЛЬНЕЙШЕГО ИСПОЛЬЗОВАНИЯ ДЛЯ ПРОИЗВОДСТВА БИОЭНЕРГИИ
}

\author{
ГОНЧАРУК И.В., \\ кандидат экономических наук, \\ доцент кафедры экономики, \\ ВОВК В.Ю., \\ аспирантка первого года обучения \\ кафедры экономики \\ Винницкий национальный аграрный университет
} (2. Винница)

В статье исследованы трактовки понятия «отходы» в европейских и отечественных нормативных документах и выявлено отсутствие в определениях экологической составляющей, что сегодня является чрезвычайно важным аспектом осуществления любого вида деятельности. Уделено внимание важной группе отходов - сельскохозяйственным отходам, которые одновременно осуществляют наиболее негативное влияние на окружающую среду и могут быть использованы в качестве вторичного сырья для обеспечения деятельности других отраслей. Приведен перечень европейских и отечественных нормативно-правовых документов, которые частично регулируют различные аспекть обращения с сельскохозяйственными отходами и выявлено отсутствие как в нормативных документах, так и среди научных подходов к определению сущиности отходов АПК, в связи с этим представлено авторское понимание данной категории отходов. Также проведено сравнение классификации сельскохозяйственных отходов в соответствии $c$ Государственным классификатором отходов Украины ДК 005-96 с классификаиией соответствующей группь отходов, приведенной в Европейском каталоге отходов.

Проанализированы объемы образования отходов в Украине по видам экономической деятельности в 2019 году. Изучена структура выбросов АПК Украины и указано, что наибольшими загрязнителями окружающей среды являются отходы животноводства (навоз животных и помет птии), однако сегодня существуют пути превращения таких отходов на биотоплива, а именно - биогаз. Осуществление прочесса переработки отходов животноводства (навоза животных и помета птии, которые являются побочными продуктами производства и которые не нужно выращивать дополнительно) в биогаз, обеспечит не только экологическую составляюшую обращения с отходами - уменьшение выбросов парниковых газов, но и предоставит дополнительные экономические выгодыл. 
Данным исследованием установлено, что переработка отходов животноводства, с образованием биогаза, позволит частично решить экологические проблемы, а также получить преимущества в виде децентрализованного производства возобновляемой энергии или производства топлива для формирования энергетической независимости сельскохозяйственной отрасли Украины и государства в целом.

Ключевые слова: энергетическая независимость, агропромышленный комплекс, сельскохозяйственные отходы, животноводство, биотопливо, биогаз, экологическая безопасность.

Табл.: 2. Рис.: 2. Лит.: 25.

Постановка проблеми. Зростаючий антропогенний вплив на довкілля, внаслідок стрімкого нераціонального використання природних ресурсів, призводить до порушення екологічної рівноваги та до загострення глобальної проблеми зміни клімату. Глобальне потепління, спричинене, насамперед, втручанням людини у природу, а саме: вирубуванням лісів та зростанням частки розораності земель, порушенням режиму вологості та вітрового режиму планети, але основною причиною даного явища $\epsilon$ збільшення емісії парникових газів внаслідок використання викопних видів палива. Відповідно до даних ООН станом на квітень 2020 р., щоденні глобальні викиди $\mathrm{CO}_{2}$ зменшились на 17\% порівняно 3 середнім рівнем 2019 р. За даними Міжурядової комісії $з$ питань зміни клімату, антропогенні викиди парникових газів у світі становлять близько 21\%; транспорт - 14\%; сільське та лісове господарство - 23\%; енергетика та видобуток $-35 \%$, житловий сектор - 6\%. Одним із найважливіших факторів негативного антропогенного впливу на довкілля $є$ значна концентрація відходів та відсутність ефективних методів їх утилізації.

Проблема відходів в Україні вирізняється особливою масштабністю i значимістю через домінування в національній економіці ресурсоємних багатовідходних технологій, так і через відсутність, протягом тривалого часу, адекватного реагування на їі виклики. Неконтрольоване накопичення відходів $\epsilon$ загрозою національній безпеці України, довкіллю та здоров’ю населення [1].

При ведені сільськогосподарського виробництва утворюється велика кількість побічних продуктів і відходів, які можуть бути використані для виробництва біопалив. До них відносять усі форми матеріалів рослинного походження, що можуть використовуватися для одержання енергії: деревину, трав'яні і зернові культури, відходи лісового господарства та тваринництва, а також побутові й промислові відходи не завжди рослинного походження, але для яких характерні однакові принципи їх утилізації.

Сьогодні сільськогосподарські відходи, хоч і є цінною сировиною, але не завжди знаходять застосування. У сільськогосподарських підприємствах не плануються показники, які б характеризували роботу щодо переробки відходів на біопаливо, підвищення родючості грунту, внесення добрив, особливо органічних. Тому й виникає необхідність у раціональному управлінні відходами.

Усе це визначає наукову проблему та актуальність іiі дослідження, що полягає у обгрунтуванні теоретичних основ розвитку сільськогосподарських 
відходів у частині категорійно-понятійного апарату.

Аналіз останніх досліджень і публікацій. Дослідженню проблем утворення відходів та пошуку ефективних способів їх утилізації присвячені праці вітчизняних і зарубіжних науковців, серед яких варто виділити роботи А. Андрейченка, О. Бондар, І. Гончарук, Т. Смчик, Г. Калетніка, I. Кириленка, Н. Пришляк, Д. Токарчук, О. Ходаківської, О. Шпикуляка, О. Шпичака та інших.

Безперечно, науковці зробили вагомий внесок у розвиток теоретичних, методологічних та організаційних положень у дослідження циркулярної економіки. Проте, сьогодні, не вирішеними залишаються питання розкриття сутності категорії сільськогосподарські відходи та їх ролі у формуванні енергетичної незалежності (безпеки).

Формулювання цілей статті. Метою дослідження $\epsilon$ обгрунтування категорійного апарату сільськогосподарських відходів та визначення їх ролі у формуванні енергетичної незалежності (безпеки) АПК.

Виклад основного матеріалу. Інтенсивність діяльності всіх суб'єктів економічних відносин щодня зростає і призводить до того, що у всіх господарських процесах обсяги утворення відходів зростають. Безвідповідальне поводження з відходами ставить під загрозу можливість впровадження у життя концепції сталого розвитку.

Зауважимо, що серед вітчизняних та зарубіжних науковців відсутня одностайність щодо визначення поняття «відходи». В економічній енциклопедії відходи визначаються, як частина продукції, яка утворилася в процесі виробництва, використання або переробки сільськогосподарської сировини та при тривалому зберіганні завдає шкоди навколишньому середовищу $[17$, с. $69-$ 70].

При ведені сільськогосподарського виробництва утворюється велика кількість побічних продуктів і відходів сільського господарства, які можуть бути використані для виробництва біопалив. До них відносять усі форми матеріалів рослинного походження, що можуть використовуватися для одержання енергіі: деревину, трав'яні і зернові культури, відходи лісового господарства та тваринництва, а також побутові й промислові відходи не завжди рослинного походження, але для яких характерні однакові принципи їх утилізації.

Нормативно-правове регулювання у сфері поводження 3 сільськогосподарськими відходами в Україні частково відображено у низці нормативних актів: Закони України «Про відходи» [4], «Про охорону навколишнього середовища» [18], «Про забезпечення санітарного та епідеміологічного благополуччя населення» [19], «Про ветеринарну медицину» [20] та інші.

У ЄС також відсутня конкретна політика щодо сільськогосподарських відходів. $Є С$ сформулював політику щодо біологічних відходів, які визначаються, як біодеградовані відходи садів і парків, продуктів харчування та кухонні відходи від домашніх господарств, ресторанів, підприємств громадського харчування і торгових приміщень, а також відходи харчової 
промисловості.

Ця політика не включає лісове господарство або сільськогосподарські відходи, гній, осад стічних вод або інші біорозкладні відходи, такі як відходи текстилю, паперу або деревообробки. Вона також виключає ті побічні продукти виробництва харчових продуктів, які ніколи не стають відходами.

Як і в Україні, у ЄС є загальне законодавство щодо відходів, з яких ми виокремили ті нормативні акти, які $\epsilon$ найбільш актуальними для сільськогосподарських відходів:

- Рамкова Директива щодо відходів 2008/98/EC [3];

- Водна Рамкова Директива (2000/60/EC) [21], спрямована на досягнення задовільного стану як підземних, так i поверхневих вод i скорочення забруднення, включаючи забруднення з сільськогосподарських джерел;

- Директива по звалищам ЄC 1999/31/EC [22], яка, зокрема, націлена на скорочення рівня біодеградовних відходів, що підлягають утилізації, на звалищі э до 75\% від рівня 1995 року;

- Директива по нітратам 91/676/EЕC [23] - про захист вод від забруднення нітратами $з$ сільськогосподарських джерел;

- Директива Ради 86/278/EEC [24] від 12 червня 1986 року про охорону навколишнього середовища - зокрема грунту, у випадках, коли стічні води використовується для задоволення потреб сільського господарства;

- Положення про побічні продукти тваринного походження і похідні продуктів, не призначені для споживання людиною (СС) 1069/2009 [25].

Для формування єдиної класифікації відходів для всіх країн-членів, СС розробив свій перелік відходів, які також називають Європейським каталогом відходів або EWC (European Waste Catalogue) [10].

Задля уточнення сутності категорії «сільськогосподарські відходи», вважаємо за необхідне висвітлити різні варіації трактування науковцями $і$ європейськими та вітчизняними нормативно-правовими актами (табл. 1).

Проаналізувавши різні підходи до трактування сутності поняття «відходи» у вітчизняних та європейських нормативно-правових документах, можемо зазначити, що жодне із наведених визначень ні у вітчизняному, ні у європейському законодавстві не є досконалим. Найчастіше враховуються такі правові аспекти, як походження, власник відходів, його наміри та обов'язки в частині поводження 3 відходами.

Проте, у всіх наведених визначеннях майже відсутні економічна та екологічна складові. Саме екологічна складова, що $є$ найбільш соціально спрямованою, повинна пронизувати всі підходи, забезпечуючи тим самим єдність пріоритетів у подоланні загальної економічної проблеми і забезпеченні екологічної безпеки. 3 економічної точки зору, важливим є врахування напрямів подальшого використання відходів, можливостей отримання майбутніх економічних вигод від їх використання або понесення витрат задля їх видалення, знешкодження тощо. 


\section{Трактування сутності категорії «сільськогосподарські відходи» вітчизняними науковцями і у нормативно-правових документах}

\begin{tabular}{|c|c|}
\hline $\begin{array}{c}\text { Вчені, нормативно- } \\
\text { правові акти }\end{array}$ & Визначення терміну \\
\hline $\begin{array}{l}\text { Національна стратегія } \\
\text { управління відходами в } \\
\text { Україні до } 2030 \text { р. [1] }\end{array}$ & $\begin{array}{l}\text { Сільськогосподарські відходи в Україні поділяються на відходи тваринництва, відходи } \\
\text { рослинництва та агрохімічні відходи. } \\
\text { До відходів виробництва продукції сільського господарства віднесено: органічні відходи } \\
\text { рослинництва; органічні відходи тваринництва та птахівництва; біовідходи (трупи тварин } \\
\text { та птиці); залишкова кількість добрив, хімічних та біологічних засобів для захисту рослин, } \\
\text { ветеринарних препаратів }\end{array}$ \\
\hline $\begin{array}{l}\text { Державний } \\
\text { класифікатор України. } \\
\text { Класифікатор } \\
\text { відходів } 005-96 \text { [6] }\end{array}$ & $\begin{array}{l}\text { Значну частину відходів АПК (більше 80\%) складають відходи сільського господарства, } \\
\text { тобто рослинництва і тваринництва. До відходів виробництва продукції сільського } \\
\text { господарства (група 01) належать: відходи виробництва зернових культур, продукції } \\
\text { овочівництва та садівництва; відходи вирощування тварин та виробництва продукції } \\
\text { тваринництва; відходи виробництва продукції змішаного господарювання; відходи від } \\
\text { надання послуг у рослинництві та тваринництві; послуги спеціалізовані щодо поводження } \\
\text { з відходами виробництва продукції сільського господарства, які надаються за місцем } \\
\text { утворення відходів. }\end{array}$ \\
\hline $\begin{array}{l}\text { Закон України «Про } \\
\text { державну підтримку } \\
\text { сільського } \\
\text { господарства України» } \\
\text { (пункт 2.15) від } 2004 \text { р. } \\
\text { [9] }\end{array}$ & $\begin{array}{l}\text { Відходи від виробництва сільськогосподарської продукції (товарів) відносяться до } \\
\text { сільськогосподарської продукції (товарів), які включають у себе: органічні добрива і } \\
\text { суміші органічних і мінеральних добрив (якщо частка органічних добрив становить } \\
\text { більше 50\% від загальної ваги таких сумішей); все біопаливо і енергію, одержувані при } \\
\text { переробці сільськогосподарської продукції (товарів) та їх відходів (біогаз, біодизель, } \\
\text { етанол, тверде біопаливо - якщо в їх виробництві використовується понад 50\% } \\
\text { сільськогосподарської продукції (ії відходів) від загального обсягу використаного } \\
\text { виробництва електроенергії, пара гарячої води тощо). }\end{array}$ \\
\hline 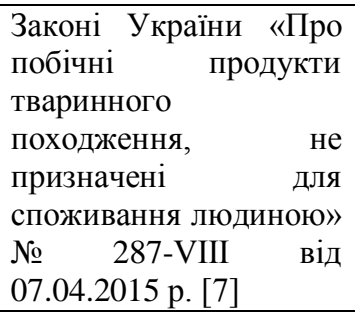 & $\begin{array}{l}\text { Цей Закон визначає організаційні та правові засади для фізичних та юридичних осіб, які } \\
\text { забезпечують діяльність, пов'язану } 3 \text { виробництвом, збором, транспортуванням, } \\
\text { зберіганням, переробкою, утилізацією і видаленням побічних продуктів тваринного } \\
\text { походження або оброблених побічних продуктів тваринного походження, які не } \\
\text { призначені для споживання людиною. Закон визначає категорії продуктів (спираючись на } \\
\text { величину ризиків для здоров'я людини і тварин), методи управління для кожної з цих } \\
\text { категорій, права та обов'язки операторів ринку, вимоги до об'єктів поводження } 3 \\
\text { відходами, а також відповідальність за порушення цих вимог. }\end{array}$ \\
\hline $\begin{array}{l}\text { Свропейський каталог } \\
\text { відходів } \quad \text { (European } \\
\text { Waste Catalogue) [10] }\end{array}$ & $\begin{array}{l}\text { До сільськогосподарських відходів належать: відходи сільського господарства, } \\
\text { садівництва, полювання, рибальства і аквакультури первинного виробництва, } \\
\text { приготування і обробки; первинні відходи виробництва; шлам після миття та очищення; } \\
\text { відходи з тканин тварин; відходи з тканин рослин; відходи з пластику (окрім пакування); } \\
\text { відходи агрохімії; фекалії тварин, сеча та гній (в т.ч. зіпсована солома); відходи від } \\
\text { використання лісів; інші відходи. }\end{array}$ \\
\hline $\begin{array}{lr}\text { Закон України } & \text { «Про } \\
\text { альтернативні } & \text { види } \\
\text { палива» [5] } & \\
\end{array}$ & $\begin{array}{l}\text { Відходи - шлаки та відходи промисловості, сільського господарства, комунально- } \\
\text { побутових та інших підприємств, які можуть бути джерелом або сировиною для } \\
\text { видобутку чи виробництва альтернативних видів палива. }\end{array}$ \\
\hline Д. Токарчук [8] & $\begin{array}{l}\text { Відходи сільського господарства - цінний вторинний та енергетичний ресурс. Частина } \\
\text { відходів і залишків використовується на потреби самого сільського господарства (у якості } \\
\text { органічного добрива, як підстилка і корм тваринам), частина - іншими галузями } \\
\text { економіки (екобудівництво, декоративно-прикладне мистецтво), a інша біомаса } \\
\text { залишається незадіяною i часто неефективно утилізується (спалюється на полях, } \\
\text { вивозиться на звалища). Натомість значну частину невикористаної біомаси доцільно } \\
\text { піддати подальшій переробці або залучити на виробництво енергії. }\end{array}$ \\
\hline $\begin{array}{l}\text { I. Гречановська [17, с. } \\
70]\end{array}$ & $\begin{array}{l}\text { Всі об’єкти підприємницької діяльності є споживачами природних ресурсів і умов, } \\
\text { виробляючи при цьому, крім дійсно необхідної продукції та послуг, специфічні продукти } \\
\text { - відходи. }\end{array}$ \\
\hline С. Шунтова $[17$, с. 70$]$ & $\begin{array}{l}\text { Відходи є неминучим наслідком виробництва, які включені у вартість товарів і самі } \\
\text { стають товаром, тобто специфічним продуктом виробництва, так як вони залучені до } \\
\text { структури системи виробництва, споживання, накопичення». }\end{array}$ \\
\hline $\begin{array}{l}\text { В. Кержакова, } \\
\text { О. Дериколенко [17, с. } \\
\text { 70] }\end{array}$ & $\begin{array}{l}\text { Відходи - це вторинні матеріальні ресурси. } 3 \text { розвитком науково-технічного прогресу } \\
\text { кількість речовин, що називаються «відходами», буде зменшуватися, бо з'являються } \\
\text { технології, сировиною для яких є відходи, що утворилися раніше. }\end{array}$ \\
\hline
\end{tabular}


Продовження таблиці 1

\begin{tabular}{|c|c|}
\hline $\begin{array}{l}\text { О. Новиков, } \\
\text { Г. Маховиков }[17, \text { с. } 70]\end{array}$ & $\begin{array}{l}\text { Відходи є вторинними матеріальними ресурсами або вторинною сировиною, і які, } \\
\text { внаслідок процесу відновлення споживчої вартості, перетворюються в новий предмет } \\
\text { праці, що здатен максимально задовольнити потреби нового процесу виробництва. }\end{array}$ \\
\hline $\begin{array}{l}\text { Рамкова Директива про } \\
\text { відходи 75/442/ЄС [2] }\end{array}$ & $\begin{array}{l}\text { Відходи - це будь-яка речовина або предмет, який власник утилізує або зобов'язаний } \\
\text { утилізувати відповідно до положень національного законодавства. }\end{array}$ \\
\hline $\begin{array}{l}\text { Директива } \\
\text { Свропейського } \\
\text { Парламенту та Ради } \\
\text { 2008/98/СС [3] }\end{array}$ & $\begin{array}{l}\text { Відходи - це будь-яка речовина чи предмет, яких власник позбувається, має намір чи } \\
\text { зобов'язаний позбутися. }\end{array}$ \\
\hline $\begin{array}{l}\text { Закон України «Про } \\
\text { відходи» [4] }\end{array}$ & $\begin{array}{l}\text { Відходи - будь-які речовини, матеріали і предмети, що утворилися у процесі виробництва } \\
\text { чи споживання, а також товари (продукція), що повністю або частково втратили свої } \\
\text { споживчі властивості і не мають подальшого використання за місцем їх утворення чи } \\
\text { виявлення і від яких їх власник позбувається, має намір або повинен позбутися шляхом } \\
\text { утилізації чи видалення. }\end{array}$ \\
\hline
\end{tabular}

Джерело: таблиия сформована авторами на основі аналізу літературних джерел та нормативно-правових актів [1-9; 10;17]

Зважаючи на відсутність понятійного апарату сільськогосподарських відходів як у європейських та вітчизняних нормативно-правових актах, так i серед напрацювань науковців, вважаємо за необхідне навести авторське розуміння сутності зазначеної категорії відходів сільського господарства як складової забезпечення енергетичної безпеки. Так, на нашу думку, сільськогосподарські відходи - це рослинницькі та тваринницькі відходи, які залишаються після виробництва або первинної переробки сільськогосподарської продукції; вирощування, розведення тварин, гній, який утворюється внаслідок їх життєдіяльності, та, у подальшому, можуть бути використані, як сировина для виробництва біопалив та забезпечення енергетичної незалежності.

За даними Державної служби статистики України, у 2019 р. у структурі загального обсягу утворення відходів за видами економічної діяльності, відходи сільського господарства становлять $1,53 \%$; частка відходів добувної промисловості - 88,46\%; переробної промисловості - 6,97\%; постачання електроенергії, газу, пари та кондиційованого повітря - 1,35\%; обсяг зібраних отриманих відходів від домогосподарств - 1,34\%; інші види економічної діяльності-0,36\% (рис. 1) [11].

Не дивлячись на ряд прийнятих стратегій та програмних документів щодо охорони навколишнього природного середовища в Україні, сфера поводження 3 відходами не була в них належно відображена, хоча такі відходи шкодять здоров'ю людей та навколишньому середовищу.

Основну частку при ведені господарської діяльності аграрних підприємств займають відходи рослинного i тваринного походження, змішані харчові відходи; тваринні екскременти, сеча та гній тощо.

Досліджуючи сільськогосподарські відходи, найбільш небезпечними для навколишнього середовища $є$ відходи тваринництва, а особливо відходи птахівництва, оскільки великі комплекси зосереджені на обмеженій території і це призводить до екологічних катастроф. Через нарощування виробництва i відсутність потужних очисних систем, відходи таких підприємств потрапляють у воду, грунт і повітря. 
EФМ

http://efm.vsau.org/

Добувна промисловість та розроблення кар'єрів 0,885

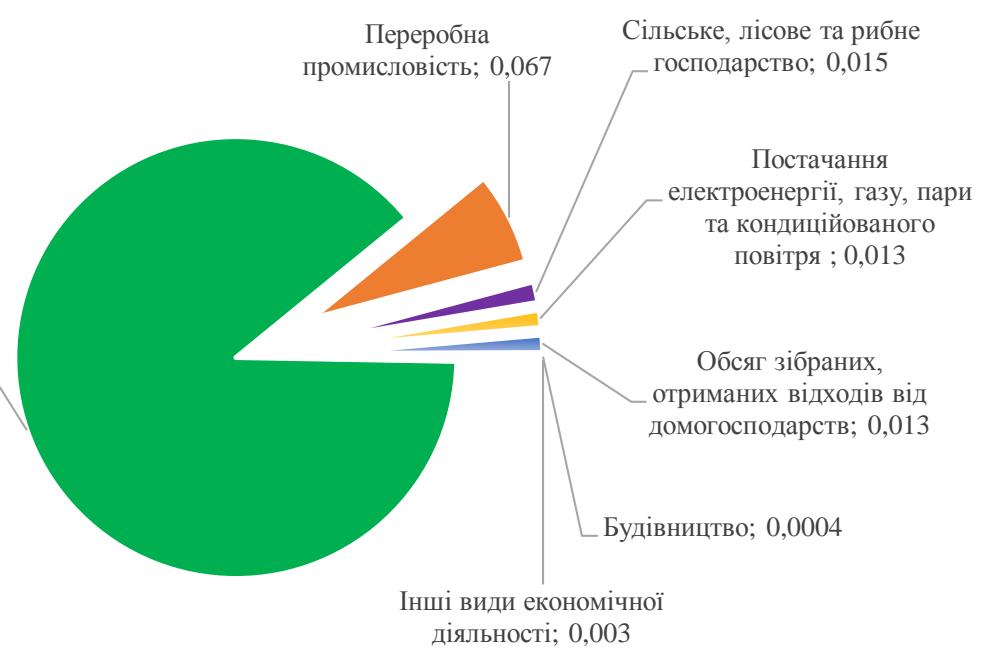

\section{Рис. 1. Обсяги утворення відходів в Україні за видами економічної} діяльності у 2019 році [11]

Джерело: сформовано автором за даними Державної служби статистики Украӥни

Деякі вчені висвітлили цю проблему у своїх публікаціях, так Гончарук I.B. у своїх працях детально дослідила структуру викидів АПК України, де зазначила, що тваринництво спричиняє $18 \%$ викидів парникових газів, зокрема викиди метану цієї галузі становлять близько $16 \%$ річного світового показника викидів, оксид азот - 17\% та багато інших небезпечних для довкілля речовин i сполук (рис. 2) [14, с. 10-11].

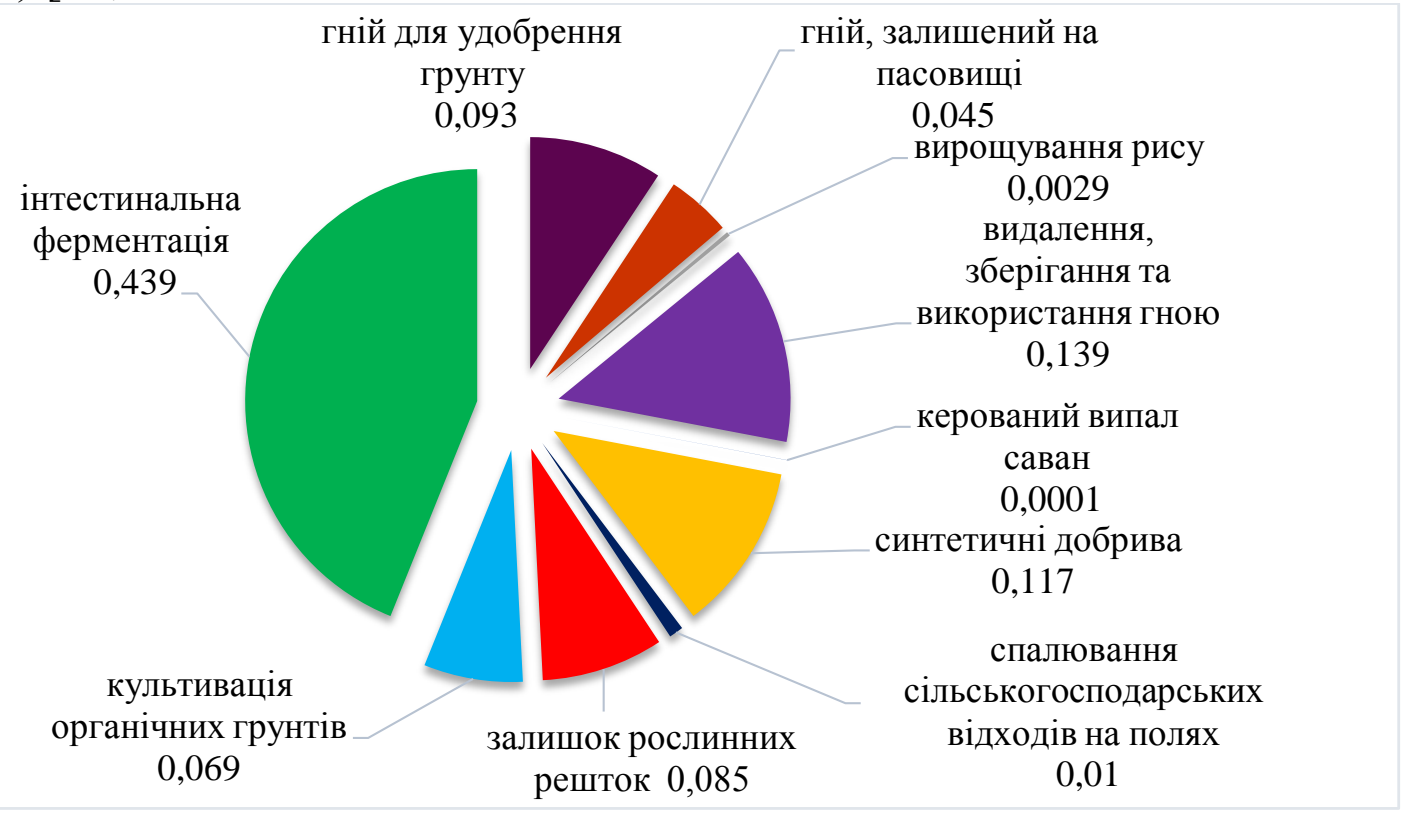

Рис. 2. Структура викидів АПК України, середній показник 3a 1990-2017 pp., $\mathrm{CO}_{2}$ equivalent

Джерело: [15, с. 11]

В умовах сьогодення багато уваги приділяють пошуку раціональних 
способів утилізації відходів, проте недостатнім, на нашу думку, є вивчення загальних аспектів використання відходів як джерела вторинної переробки. Нині все більше відходів виступають сировиною для інших галузей, наприклад, сільськогосподарські відходи тваринного походження $\epsilon$ джерелом для виробництва біогазу та інших видів біопалив. Використання тваринницьких відходів для цілей біоенергетики надасть можливість посилити (забезпечити) енергетичну (безпеку) незалежність галузі і зменшити антропогенний вплив на довкілля.

Утилізація відходів $\epsilon$ переважаючим типом поводження з екскрементами тварин, за допомогою цього методу знищено вдвічі більше відходів, ніж за допомогою вироблення продукції 3 відходів тварин/змішаних харчових продуктів. Інсінерація $\epsilon$ найбільш розповсюдженим способом поводження 3 рослинними відходами, тобто 461.2 тис. тон було спалено для отримання енергії в 2019 році. Утилізація трьох основних видів сільськогосподарських відходів наразі недостатньо практикується в Україні (табл. 2) [11].

Утворення та поводження з відходами I-IV класів небезпеки за категоріями матеріалів у сільському господарстві України у 2019 рр., тис.т.

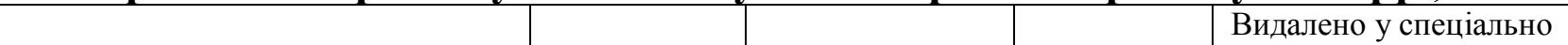

\begin{tabular}{l|c|c|c|c|}
\multicolumn{1}{|c|}{ Показник } & Утворено & Утилізовано & Спалено & $\begin{array}{c}\text { Видалено у спеціально } \\
\text { відведені місця чи } \\
\text { об'єкти }\end{array}$ \\
\hline $\begin{array}{l}\text { Відходи тваринного походження та } \\
\text { змішані харчові відходи }\end{array}$ & 441,0 & 230,8 & 11,7 & 2,3 \\
\hline Відходи рослинного походження & 8068,6 & 2361,1 & 461,2 & 17,3 \\
\hline Тваринні екскременти, сеча та гній & 3612,0 & 2407,0 & - & 30, \\
\hline
\end{tabular}
Джсерело: таблиия сформована авторами за даними Державної служби статистики
Украйни [11]

Калетнік Г.М. у своїх наукових працях обгрунтував важливість розвитку агропромислового комплексу України у вирішенні проблем енергетичної та екологічної безпеки держави. Вченим найбільш комплексно було розглянуто поняття забезпечення енергетичної незалежності за рахунок використання сільськогосподарських відходів у якості сировини для виробництва біопалива $[12 ; 13]$.

Сільськогосподарські відходи, в основному відходи тваринництва, такі як гній, курячий послід можуть бути додатковим джерелом поповнення енергетичного балансу сільськогосподарських підприємств та забезпечення енергетичної незалежності галузі.

Україна має невикористаний потенціал для виробництва власної енергії 3 відновлюваних джерел за рахунок переробки відходів тваринного походження (гній тварин і послід птахів) з утворенням біогазу. Біогаз, отриманий із біомаси, використовується як паливо, не шкідливе для оточуючого середовища, оскільки не спричиняє додаткову емісію парникового газу $\mathrm{CO}_{2}$ i зменшує кількість органічних відходів. На відміну від енергії вітру і сонячного випромінювання, біогаз можна отримувати незалежно від кліматичних і погодних умов. 
Біогаз як продукт біоперетворення, що має високий вміст метану, може (бути) використовуватись для отримання електроенергії, яка, в свою чергу, реалізується за «зеленим тарифом»; тепло для власних потреб підприємства або на продаж; гарячу воду, а також використовувати органічні відходи біогазової установки (дигестат) як добриво [15, с. 26 ].

Гончарук I.B. та Томашук I.В., досліджуючи перспективи використання сільськогосподарських відходів для забезпечення енергетичної незалежності, зазначають, що кожного року на великих тваринницьких фермах та птахофабриках анаеробним способом можна отримувати екологічно чисті біодобрива і значно покращувати якість стічних вод. Переробка гною від однієї корови за рік дає біля $500 \mathrm{~m}^{3}$ біогазу. 31 т свіжого гною великої рогатої худоби можна отримати 30-50 $\mathrm{m}^{3}$ біогазу, свиней $-50-80 \mathrm{~m}^{3}$, соломи та трави $-30-60 \mathrm{~m}^{3}$. Біотехнологія передбачає комплексну переробку та утилізацію відходів. Застосування анаеробного бродіння гною дозволяє з 37 кг азоту повернути в грунт у вигляді добрива 36 кг, а при звичайному бродінні - 12-15 кг [16, с. 13].

Підсумовуючи зазначимо, що утилізація сільськогосподарських відходів, а саме відходів тваринництва шляхом їх переробки на біогаз, $є$ важливим аспектом не тільки екологічності даного процесу, але містить енергетичну складову забезпечення енергетичної незалежності, тобто використання власної відновлюваної сировинної бази і відмова від викопних енергоносіїв або імпорту, диверсифікації енергопостачання. Проте, економічні вигоди від використання біогазу в кожному конкретному випадку залежатимуть від типу відходів, доступних для переробки, інвестиційних можливостей, наявності локального енергетичного ринку та державних ініціатив.

Висновки. Сільськогосподарські відходи сьогодні $\epsilon, 3$ одного боку, джерелом забруднення навколишнього середовища, а з іншого боку, саме даний вид відходів, можна перетворити екологічно безпечним шляхом на енергію та паливо, і тим самим забезпечити енергетичну незалежність. Проаналізувавши низку європейських та вітчизняних нормативних документів із питань регулювання утворення відходів загалом та сільськогосподарських відходів зокрема, ми виявили відсутність чіткого визначення категорії «сільськогосподарські відходи» як у нормативно-правових актах, так і серед думок або напрацювань науковців, тому авторами запропоновано власний підхід до розуміння сутності зазначеної категорії відходів.

Україна має незадіяний потенціал розвитку відновлюваних джерел енергії - виробництво біогазу з відходів тваринництва, саме з гною тварин та посліду птахів. Одним із основних моментів щодо виробництва біогазу 3 відходів тваринництва $€$ можливість не тільки вирішити екологічні проблеми поводження 3 відходами, але і отримати економічні переваги. Гній та послід $є$ побічними продуктами тваринництва, їх утворення у великій кількості $\epsilon$ основним джерелом нітратного забруднення грунтів, поверхневих та підземних вод. Відходи тваринництва також спричиняють викиди парникових газів у атмосферне повітря, що має значний вплив на довкілля та призводить до 
загострення глобальних екологічних проблем, таких, як глобальне потепління та зміна клімату.

\section{Список використаних джерел}

1. Про схвалення Національної стратегії управління відходами в Україні до 2030 року. URL: https://zakon.rada.gov.ua/laws/show/820-2017-\%D1\%80\#Text (дата звернення 20.10.2020).

2. Рамкова Директива про відходи 75/442/ЄС від 15 липня 1975 р. рішенням Європейської Ради. URL: https://eur-lex.europa.eu/legalcontent/EN/TXT/PDF/?uri=CELEX:31975L0442\&from=EN (дата звернення 18.10.2020).

3. Директива Європейського Парламенту та Ради 2008/98/ЄС від 19 листопада 2008 року про відходи та скасування деяких Директив. URL: https://mepr.gov.ua/files/docs/2008\%2098\%20\%D0\%84\%D0\%A1.pdf (дата э звернення 18.10.2020).

4. Про відходи: Закон України від 05.03.1998 p. №187/98-ВР. URL: https://zakon.rada.gov.ua/laws/show/187/98-\%D0\%B2\%D1\%80\#Text (дата звернення 20.10.2020).

5. Про альтернативні види палива. Закон України від 14.01.2000 p. №1391XIV URL: https://zakon.rada.gov.ua/laws/show/1391-14\#Text (дата звернення 20.10.2020).

6. Державний класифікатор України. Класифікатор відходів ДК 005-96, затверджений наказом Держстандарту України від 29.02.1996 p. № 89. URL: http://www.zakon/nau.ua (дата звернення 21.10.2020).

7. Про побічні продукти тваринного походження, не призначені для споживання людиною: Закон України № 287-VIII від 07.04.2015. URL: https://zakon.rada.gov.ua/laws/show/287-19\#Text (дата звернення 9.10.2020).

8. Токарчук Д.М. Управління ефективним використанням сільськогосподарських відходів для виробництва біогазу. Облік $i$ фінанси. №3(81). 2018. С. 133-139.

9. Про державну підтримку сільського господарства України: Закон України №1877-IV від 24/06/2004. URL: https://zakon.rada.gov.ua/laws/show/187715\#n15 (дата звернення 20.10.2020).

10. European Waste Catalogue. URL: https://eur-lex.europa.eu/legalcontent/EN/TXT/?uri=CELEX:02000D0532-20150601.

11. Офіційний сайт Державної служби статистики України. URL: http://www.ukrstat.gov.ua (дата звернення 18.10.2020).

12. Калетнік Г.М. Роль агропромислового комплексу України у вирішенні проблем енергетичної та екологічної безпеки держави. Агросвіт. 2009. № 22. C. $2-5$.

13. Калетнік Г.М. Диверсифікація розвитку виробництва біопалив - основа забезпечення продовольчої, енергетичної, економічної та екологічної безпеки України. Вісник аграрної науки. 2018. №11. С. 169-176. 
14. Honcharuk I. Use of Wastes of the Livestock Industry as a Possibility for Increasing the Efficiency of AIC and Eeplenishing the energy Balance. Visegrad Journal on Bioeconomy and Sustainable Development. 2020. vol. 9. № 1. P. 9-14.

15. Гончарук I. В. Виробництво біогазу в аграрному секторі - шлях до підвищення енергетичної незалежності та родючості грунтів. Агросвіт. 2020. № 15. C. 18-29.

16. Гончарук I.В., Томашук I.В. Економічна ефективність енергетичної автономії АПК за рахунок використання біопалив. Економіка. Фінанси. Менеджмент: актуальні питання науки і практики. 2019. № 2. С. 7-19.

17. Андрейченко А.В, Типологія відходів в АПК: вітчизняний та європейський досвід. Економічний простір. 2017. № 124. С. 67-76

18. Про охорону навколишнього середовища: Закон України від 19.06.1991 p. № 1264-XII. URL: https://zakon.rada.gov.ua/laws/show/1264-12\#Text (дата звернення 18.10.2020).

19. Про забезпечення санітарного та епідеміологічного благополуччя населення: Закон України від 24.02.1994 p. № 4004-XII. URL: https://zakon.rada.gov.ua/laws/show/4004-12\#Text (дата звернення 21.10.2020).

20. Про ветеринарну медицину: Закон України від 25.06.1992 р. № 2498XII. URL: https://zakon.rada.gov.ua/laws/show/2498-12\#Text (дата звернення 21.10.2020).

21. Directive 2000/60/EC of the European Parliament and of the Council of 23 October 2000 establishing a framework for Community action in the field of water policy. URL: https://eur-lex.europa.eu/legal-content/EN/TXT/?uri=CELEX :32000L0060 (дата звернення 21.10.2020).

22. Council Directive 1999/31/EC of 26 April 1999 on the landfill of waste. URL: https://eur-lex.europa.eu/legal-content/EN/TXT/?uri=celex\%3A31999L0031 (дата звернення 21.10.2020).

23. Consolidated text: Council Directive of 12 December 1991 concerning the protection of waters against pollution caused by nitrates from agricultural sources (91/676/EEC). URL: https://eur-lex.europa.eu/legal-content/EN/TXT/?qid $=1561542776070 \& u r i=C E L E X: 01991 L 0676-20081211$ (дата звернення 20.10.2020).

24. Council Directive 86/278/EEC of 12 June 1986 on the protection of the environment, and in particular of the soil, when sewage sludge is used in agriculture. URL: https://eur-lex.europa.eu/legal-content/EN/TXT/?uri=celex\%3A31986L0278 (дата звернення 20.10.2020).

25. Regulation (EC) No 1069/2009 of the European Parliament and of the Council of 21 October 2009 laying down health rules as regards animal by-products and derived products not intended for human consumption and repealing Regulation (EC) No 1774/2002 (Animal by-products Regulation). URL: https://eurlex.europa.eu/legal-content/EN/ALL/?uri=CELEX\%3A32009R1069 (дата звернення 18.10.2020). 


\section{References}

1. Pro skhvalennia Natsionalnoi stratehii upravlinnia vidkhodamy v Ukraini do 2030 roku [On approval of the National Waste Management Strategy in Ukraine until 2030]. Retrieved from: https://zakon.rada.gov.ua/laws/show/820-2017$\% \mathrm{D} 1 \% 80 \#$ Text [in Ukrainian].

2. Ramkova Dyrektyva pro vidkhody 75/442/YeS vid 15 lypnia 1975 r. rishenniam Yevropeiskoi Rady [Waste Framework Directive 75/442 / EC of 15 July 1975 by Decision of the European Council]. Retrieved from: https://eurlex.europa.eu/legal-content/EN/TXT/PDF/?uri=CELEX:31975L0442\&from=EN [in Ukrainian].

3. Dyrektyva Yevropeiskoho Parlamentu ta Rady 2008/98/YeS vid 19 lystopada 2008 roku pro vidkhody ta skasuvannia deiakykh Dyrektyv [Directive 2008/98 / EC of the European Parliament and of the Council of 19 November 2008 on waste and repealing certain

Directives].

Retrieved

from:

https://mepr.gov.ua/files/docs/2008\%2098\%20\%D0\%84\%D0\%A1.pdf [in Ukrainian].

4. Pro vidkhody: Zakon Ukrainy vid 05.03.1998 r. \#187/98-VR [On waste: Law of Ukraine of March 5, 1998 №187 / 98-VR]. Retrieved from: https://zakon.rada.gov.ua/laws/show/187/98-\%D0\%B2\%D1\%80\#Text [in Ukrainian].

5. Pro alternatyvni vydy palyva. Zakon Ukrainy vid 14.01.2000 r. \#1391-XIV [About alternative fuels. Law of Ukraine of January 14, 2000 №1391-XIV]. Retrieved from: https://zakon.rada.gov.ua/laws/show/1391-14\#Text [in Ukrainian].

6. Klasyfikator vidkhodiv DK 005-96. [Classifier of waste DK 005-96]: Order of the State Committee of Ukraine for Standardization, Metrology and Certification dated 29.02.1996 №89]. Retrieved from: http://www.zakon/nau.ua [in Ukrainian].

7. Pro pobichni produkty tvarynnoho pokhodzhennia, ne pryznacheni dlia spozhyvannia liudynoiu: Zakon Ukrainy \# 287-VIII vid 07.04.2015. [On animal byproducts not intended for human consumption: Law of Ukraine № 287-VIII of 07.04.2015]. Retrieved from: https://zakon.rada.gov.ua/laws/show/287-19\#Text [in Ukrainian].

8. Tokarchuk D.M. (2018). Upravlinnia efektyvnym vykorystanniam silskohospodarskykh vidkhodiv dlia vyrobnytstva biohazu [Management of efficient use of agricultural waste for biogas production]. Oblik $i$ finansy - Accounting and finance, 3(81), 133-139 [in Ukrainian].

9. Pro derzhavnu pidtrymku silskoho hospodarstva Ukrainy: Zakon Ukrainy \#1877-IV vid 24/06/2004 [On state support of agriculture of Ukraine: Law of Ukraine №1877-IV of 24/06/2004]. Retrieved from: https://zakon.rada.gov.ua/laws/show/1877-15\#n15 [in Ukrainian].

10. European Waste Catalogue. Retrieved from: https://eur-lex.europa.eu/legalcontent/EN/TXT/?uri=CELEX:02000D0532-20150601 [in English].

11. Ofitsiinyi sait Derzhavnoi sluzhby statystyky Ukrainy [Official site of the State Statistics Service of Ukraine]. Retrieved from: http://www.ukrstat.gov.ua/ 


\section{EФM}

http://efm.vsau.org/

[in Ukrainian].

12. Kaletnik G.M. (2009). Rol ahropromyslovoho kompleksu Ukrainy u vyrishenni problem enerhetychnoi ta ekolohichnoi bezpeky derzhavy [The role of the agro-industrial complex of Ukraine in solving the problems of energy and environmental security of the state]. Ahrosvit-Agrosvit, 22, 2-5 [in Ukrainian].

13. Kaletnik G.M. (2018). Dyversyfikatsiia rozvytku vyrobnytstva biopalyv osnova zabezpechennia prodovolchoi, enerhetychnoi, ekonomichnoi ta ekolohichnoi bezpeky Ukrainy [Diversification of biofuel production development is the basis for ensuring food, energy, economic and environmental security of Ukraine]. Visnyk ahrarnoi nauky - Bulletin of Agricultural Science, 11, 169-176 [in Ukrainian].

14. Honcharuk I. (2020). Use of Wastes of the Livestock Industry as a Possibility for Increasing the Efficiency of AIC and Eeplenishing the energy Balance. Visegrad Journal on Bioeconomy and Sustainable Development, vol. 9. № 1, 9-14 [in English].

15. Honcharuk I.V. (2020). Vyrobnytstvo biohazu v ahrarnomu sektori - shliakh do pidvyshchennia enerhetychnoi nezalezhnosti ta rodiuchosti hruntiv [Biogas production in the agricultural sector - a way to increase energy independence and soil fertility]. Ahrosvit-Agrosvit, 15, 18-29 [in Ukrainian].

16. Honcharuk I.V., \& Tomashuk I.V. (2019). Ekonomichna efektyvnist enerhetychnoi avtonomii APK za rakhunok vykorystannia biopalyv [Economic efficiency of energy autonomy of agro-industrial complex due to the use of biofuels]. Ekonomika. Finansy. Menedzhment: aktualni pytannia nauky i praktyky - Economy. Finances. Management: current issues of science and practice, 2, 7-19 [in Ukrainian].

17. Andreichenko A.V. (2017). Typolohiia vidkhodiv v APK: vitchyznianyi ta yevropeiskyi dosvid [Typology of waste in agro-industrial complex: domestic and European experience]. Ekonomichnyi prostir - Economic space, 1246 67-76 [in Ukrainian].

18. Pro okhoronu navkolyshnoho seredovyshcha: Zakon Ukrainy vid 19.06.1991 r. \# 1264-XII [On environmental protection: Law of Ukraine of June 19, 1991 № 1264XII]. Retrieved from: https://zakon.rada.gov.ua/laws/show/1264-12\#Text [in Ukrainian].

19. Pro zabezpechennia sanitarnoho ta epidemiolohichnoho blahopoluchchia naselennia: Zakon Ukrainy vid 24.02.1994 r. \# 4004-XII [On ensuring the sanitary and epidemiological well-being of the population: Law of Ukraine of 24.02.1994 № 4004XII]. Retrieved from: https://zakon.rada.gov.ua/laws/show/4004-12\#Text [in Ukrainian].

20. Pro veterynarnu medytsynu: Zakon Ukrainy vid 25.06.1992 r. \# 2498-XII [On veterinary medicine: Law of Ukraine of 25.06.1992 № 2498-XII]. Retrieved from: https://zakon.rada.gov.ua/laws/show/2498-12\#Text [in Ukrainian].

21. Directive 2000/60/EC of the European Parliament and of the Council of 23 October 2000 establishing a framework for Community action in the field of water policy. Retrieved from: https://eur-lex.europa.eu/legalcontent/EN/TXT/?uri=CELEX:32000L0060 [in English].

22. Council Directive 1999/31/EC of 26 April 1999 on the landfill of waste. 
Retrieved from: https://eur-lex.europa.eu/legal-content/EN/TXT/?uri= celex\%3A31999L0031 [in English].

23. Consolidated text: Council Directive of 12 December 1991 concerning the protection of waters against pollution caused by nitrates from agricultural sources (91/676/EEC). Retrieved from: https://eur-lex.europa.eu/legal-content /EN/TXT/?qid=1561542776070\&uri=CELEX:01991L0676-20081211 [in English].

24. Council Directive 86/278/EEC of 12 June 1986 on the protection of the environment, and in particular of the soil, when sewage sludge is used in agriculture. Retrieved from: https://eur-lex.europa. eu/legal-content/ EN/TXT/?uri=celex\%3A31986L0278 [in English].

25. Regulation (EC) No 1069/2009 of the European Parliament and of the Council of 21 October 2009 laying down health rules as regards animal by-products and derived products not intended for human consumption and repealing Regulation (EC) No 1774/2002 (Animal by-products Regulation). Retrieved from: https://eurlex.europa.eu/legal-content/EN/ALL/?uri=CELEX\%3A32009R1069 [in English].

\section{Відомості про автора}

ГОНЧАРУК Інна Вікторівна - кандидат економічних наук, доцент кафедри економіки Вінницького національного аграрного університету (вул. Сонячна, 3, м. Вінниця, 21008, email: vnaunauka2020@gmail.com).

ВОВК Валерія Юріївна - аспірантка першого року навчання кафедри економіки Вінницького національного аграрного університету (вул. Сонячна, 3 , м. Вінниця, 21008, email: vvovk_2703@ukr.net).

HONCHARUK Inna - PhD in Economics, Associate Professor, Department of Economics, Vinnytsia National Agrarian University (21008, Vinnytsia, 3 Soniachna st, e-mail: vnaunauka2020@gmail.com).

VOVK Valeria - graduate student of the first year of study of the Department of Economics, Vinnytsia National Agrarian University (21008, Vinnytsia, 3 Soniachna st, e-mail: vvovk_2703@ukr.net).

ГОНЧАРУК Инна Викторовна - кандидат экономических наук, доцент кафедры экономики Винницкого национального аграрного университета (ул. Солнечная, 3, г. Винница, 21008, e-mail: vnaunauka2020@gmail.com).

ВОВК Валерия Юрьевна - аспирантка первого года обучения кафедры экономики Винницкого национального аграрного университета (ул. Солнечная, 3, г. Винница, 21008, e-mail: vvovk_2703@ukr.net). 